\title{
ANALISIS KESALAHAN JAWABAN PESERTA DIDIK DALAM MENYELESAIKAN SOAL CERITA MATERI SISTEM PERSAMAAN LINEAR DUA VARIABEL BERDASARKAN PROSEDUR NEWMAN DI KELAS X PERKANTORAN SMK YPK BETHLEHEM ARSO 1
}

\author{
Yosefin Rianita Hadiyanti ${ }^{1)}$, Dewi Kristika Findia Ning Tyas ${ }^{2)}$ \\ ${ }^{1,2}$ Program Studi Pendidikan Matematika, FKIP, Universitas Cenderawasih \\ yosefinhadiyanti9578@gmail.com ${ }^{1)}$,dewi.findianingtyas@ fkip.uncen.ac.id ${ }^{2)}$
}

\begin{abstract}
Abstrak
Aplikasi soal-soal cerita pada materi Sistem Persamaan Linear Dua Variabel (SPLDV) membawa peserta didik ke dalam permasalahan kehidupan sehari-hari. Sangat penting mengetahui kesalahan-kesalahan peserta didik dalam mengerjakan soal-soal pada materi SPLDV serta penyebab kesalahan tersebut. Apabila penyebab kesalahan sudah diketahui, maka peserta didik yang bersangkutan diharapkan bisa menghindari kesalahan yang sama. Dalam menganalisis jenis kesalahan peserta didik berdasarkan Newman dalam Karnasih (2015: 40) menyatakan ada 5 prosedur yang ditemukan oleh Anne Newman tersebut yang diantaranya adalah membaca masalah (reading), memahami masalah (comprehension), transformasi masalah (transformasi), keterampilan proses (process skill), dan pengkodean/ penarikan kesimpulan (encoding). Hasil penelitian diperoleh bahwa: Jenis kesalahan yang dilakukan subjek dalam menyelesaikan soal cerita persamaan linear dua variabel berdasarkan prosedur Newman adalah 1) Kesalahan memahami masalah, Kesalahan memahami masalah yang dilakukan yaitu subjek tidak dapat menentukan apa yang diketahui dan ditanyakan; 2)Kesalahan transformasi, Kesalahan transformasi yang dilakukan yaitu subjek tidak dapat membuat model matematis dari informasi. Faktor-faktor yang menyebabkan siswa melakukan kesalahan dalam menyelesaikan soal cerita pada materi persamaan linear dua variabel adalah kurangnya penguasaan bahasa pada soal, Tidak teliti, Tidak dapat merencanakan strategi/rumus karena tidak menguasai materi, baik materi prasyarat maupun materi yang dipelajari. Tidak memeriksa kembali hasil pekerjaan yang telaha dikerjakan.
\end{abstract}

Kata Kunci: Kesalahan Jawaban, Peserta Didik, Soal Cerita, Persamaan Linear, Newman

\section{PENDAHULUAN}

Permasalahan yang terjadi di dalam kehidupan sehari-hari yang terkait dengan materi/konsep matematika diberikan kepada peserta didik dalam bentuk soal cerita. Menurut Utomo (Ifanali, 2014: 147) bahwa soal berbentuk cerita dalam matematika sulit untuk diselesaikan, ini terjadi antara lain karena kurangnya kemampuan peserta didik dalam mengubah kalimat verbal menjadi model matematika. Salah satu materi/konsep matematika yang berbentuk soal cerita adalah Sistem Persamaan Linear Dua Variabel.

Bentuk soal-soal cerita pada materi Sistem Persamaan Linear Dua Variabel akan membawa peserta didik ke dalam permasalahan kehidupan sehari-hari. Peserta didik harus mengubah soal-soal tersebut ke dalam bentuk model matematika. Sangat penting bagi seorang guru untuk mengetahui kesalahan-kesalahan dan penyebab yang dilakukan peserta didik dalam mengerjakan soal-soal pada materi Sistem Persamaan Linear Dua Variabel. Apabila penyebab kesalahan sudah diketahui, maka peserta didik yang bersangkutan diharapkan bisa menghindari kesalahan yang sama.

Adapun tahapan-tahapan analisis kesalahan yang dilakukan siswa dalam mengerjakan soal cerita berdasarkan prosedur Newman atau NEA. NEA dirancang sebagai prosedur diagnostik sederhana dalam menyelesaikan soal cerita matematis. Newman dalam Karnasih (2015: 40) menyatakan ada 5 
prosedur yang ditemukan oleh Anne Newman tersebut yang diantaranya adalah membaca masalah (reading), memahami masalah (comprehension), transformasi masalah (transformasi), keterampilan proses (process skill), dan pengkodean/ penarikan kesimpulan (encoding).

\section{METODE PENELITIAN}

Berdasarkan tujuan penelitian, maka penelitian ini termasuk dalam penelitian deskriptif dengan menggunakan pendekatan kualitatif. Menurut Arikunto (2013: 234) bahwa penelitian deskriptif merupakan penelitian yang bertujuan untuk mengumpulkan informasi mengenai status suatu gejala yang ada, yaitu keadaan gejala menurut apa adanya pada saat penelitian dilakukan. Penelitian ini dilaksanakan di SMK YPK Bethlehem Arso 1 yang berlokasi di Jl. Cempaka, Kamp, Sanggaria, Distrik Arso Kabupaten Keerom. Subjek dalam penelitian adalah peserta didik kelas X SMK YPK Bethlehem Arso 1. Dalam menentukan subjek penelitian digunakan teknik purposive sampling (pengambilan subjek berdasarkan tujuan) dengan menetapkan kriteria pemilihan subjek. Menurut Sugiyono (2015:300), “purposive sampling" adalah teknik penentuan sampel dengan kriteriakriteria tertentu". Kriteria subjek dalam penelitian ini adalah 1) Subjek merupakan peserta didik yang paling banyak melakukan kesalahan dalam menyelesaikan soal tes; 2) Subjek dapat mengemukakan pendapat secara lisan maupun tulisan; 3) Subjek merupakan peserta didik yang selalu aktif mengikuti pembelajaran matematika. Instrumen penelitian yang akan digunakan dalam penelitian ini adalah: 1) Instrumen utama, Menurut Sugiyono (2015:305), dalam penelitian kualitatif instrumen atau alat penelitian utama yaitu peneliti sendiri dan tidak dapat digantikan dengan instrumen lain; 2)Instrumen pendukung, Instrumen pendukung yang digunakan dalam penelitian ini yaitu lembar tes uraian. Lembar tes merupakan lembar yang berisi soal pada materi SPLDV. Ada beberapa macam bentuk tes. Dalam penelitian ini digunakan tes dalam bentuk uraian (essai). Teknik pengumpulan data dalam penelitian ini yaitu tes. Tes yang digunakan adalah bentuk tes tertulis. Tes tertulis adalah sekumpulan item pertanyaan dan atau pertanyaan yang direncanakan oleh peneliti secara sistematis, guna memperoleh informasi tentang subjek penelitian (Sukardi, 2015: 93). Menurut Sugiyono (2015 : 335), analisis data adalah proses mencari dan menyusun secara sistematis data yang diperoleh dari hasil wawancara, catatan lapangan, dan dokumentasi sehingga mudah di pahami oleh diri sendiri maupun orang lain. Analisis data dalam penelitian kualitatif dilakukan sejak sebelum memasuki lapangan, selama dilapangan dan setelah selesai di lapangan. Menurut Sugiyono (2015: 338), terdapat tiga tahapan menganalisis data dalam penelitian kualitatif, yaitu: 1) Reduksi data; 2) Penyajian data; 3) Menarik simpulan atau verifikasi.

\section{HASIL DAN PEMBAHASAN}

Penelitian ini dilaksanakan di SMK YPK Bethlehem Arso 1 Keerom yang beralamat di Jalan Cempaka Kelurahan Sanggaria Arso 2 Distrik Arso Kabupaten Keerom.

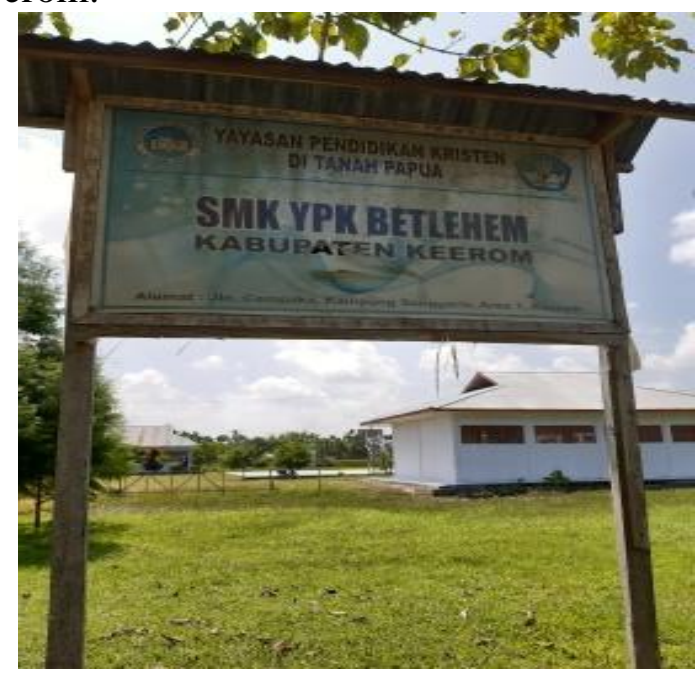

Gambar 1 Identitas sekolah tempat penelitian

Subjek dalam penelitian ini yaitu siswa kelas X Perkantoran SMK YPK Bethlehem Arso 1 yang yang berjumlah 3 (tiga) orang. 
Adapun alur/proses dalam menentuka tiga subjek tersebut yaitu 18 Siswa kelas X Perkantoran mengerjakan soal tes berjumlah 3 soal yang memuat materi system persamaan Linear Dua Variabel. Adapun soal tes yaitu:

1. Sebuah bilangan terdiri dari dua angka, penjumlahan tiga kali angka puluhan dan angka satuannya adalah 27, sedangkan selisihnya adalah 5. Tentukan bilangan tersebut!

2. Selisih usia A dan B adalah 2 tahun (A lebih tua dari B). Dua kali usia A ditambah usia B sama dengan 52 tahun. Tentukan usia A dan usia B!

3. Mesin produksi A menghasilkan 100 unit barang per jam, sedangkan mesin produksi B menghasilkan 150 unit per jam. Dalam satu hari kedua mesin itu diharapkan dapat menghasilkan 2.600 unit barang. Jumlah jam kerja dalam sehari untuk mesin A dan mesin B adalah 20 jam. Berapa jam mesin A dan mesin B harus bekerja dalam satu hari?
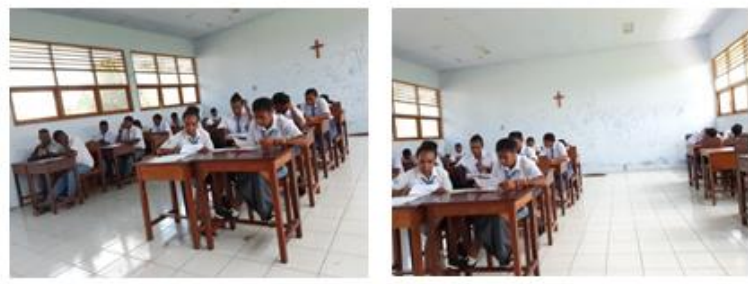

\section{Gambar 2 siswa mengerjakan tes}

Lembar jawaban tes ke-18 siswa dikoreksi, kemudian Peneliti menggunakan teknik purposive sampling dalam menentukan subjek penelitian. Subjek penelitian yang dipilih sebanyak tiga orang. Kriteria dalam pemilihan subjek penelitian, yakni: 1) Subjek merupakan peserta didik yang paling banyak melakukan kesalahan dalam menyelesaikan soal tes; 2) Subjek dapat mengemukakan pendapat secara lisan maupun tulisan; 3) Subjek merupakan peserta didik yang selalu aktif mengikuti pembelajaran matematika. Berdasarkan kriteria tersebut terpilih 3 subjek sebagai berikut.
Tabel 1. Daftar Subjek Penelitian

\begin{tabular}{|l|c|c|c|}
\hline Subjek & AMS & AS & MEP \\
\hline Kode Subjek & S1 & S2 & S3 \\
\hline
\end{tabular}

Dalam memecahkan masalah untuk menyelesaikan soal cerita materi aritmetika sosial berdasarkan prosedur Newman, Peserta didik diharapkan dapat melakukan langkahlangkah penyelesaian sebagai berikut:

1. Membaca soal, dengan indikator:

a) Membaca soal dengan benar

b) Mengenal $/$ membaca simbol-simbol yang ada pada soal.

Subjek dikatakan dapat membaca soal jika tidak melakukan kesalahan yang termasuk dalam indikator membaca soal tersebut.

2. Memahami masalah, dengan indikator:

a) Memahami arti keseluruhan dari suatu soal.

b) Menuliskan dan menjelaskan apa yang diketahui dari soal.

c) Menuliskan dan menjelaskan apa yang ditanya dari soal.

Subjek dikatakan dapat memahami masalah jika tidak melakukan kesalahan yang termasuk dalam indikator memahami masalah tersebut.

3. Transformasi, dengan indikator:

a) Menentukan rumus yang akan digunakan untuk menyelesaikan soal.

b) Menentukan operasi matematika atau rangkaian operasi untuk menyelesaikan permasalahan dalam soal dengan tepat.

c) Mengidentifikasi operasi atau serangkaian operasi.

Subjek dikatakan dapat transformasi jika tidak melakukan kesalahan yang termasuk dalam indikator transformasi tersebut.

4. Keterampilan proses, dengan indikator:

a) Mengetahui proses/algoritma untuk menyelesaikan soal meskipun sudah bisa menentukan rumus dengan tepat.

b) Menjalankan prosedur/tahap-tahap operasi hitung dengan benar. 
Subjek dikatakan dapat keterampilan proses jika tidak melakukan kesalahan yang termasuk dalam indikator keterampilan proses tersebut.

5. Penulisan jawaban, dengan indikator:

a) Menuliskan jawaban yang dimaksudkan dengan tepat sehingga tidak menyebabkan berubahnya makna jawaban yang dituliskan.

b) Mengungkapkan solusi dari soal yang dikerjakan dalam bentuk tertulis yang dapat diterima.

c) Menuliskan kesimpulan dengan tepat dari hasil pekerjaan yang diperoleh.

Subjek dikatakan dapat penulisan jawaban jika tidak melakukan kesalahan yang termasuk dalam indikator penulisan jawaban tersebut.

\section{Paparan Hasil Penelitian}

Adapun paparan hasil penelitian meliputi rekapan hasil nilai tes siswa dan hasil pekerjaan ketiga subjek mengerjakan ketiga soal tes.

1. Rekap Nilai Hasil Tes Siswa

Rekap nilai hasil tes ke-18 siswa sebagai berikut:

Tabel 2 Rekap Nilai Hasil Tes
\begin{tabular}{|l|l|l|}
\hline No & Inisial Nama Siswa & Nilai \\
\hline 1 & ANS & 0 \\
\hline 2 & ANIT & 20 \\
\hline 3 & SS & 65 \\
\hline 4 & MR & 60 \\
\hline 5 & AA & 60 \\
\hline 6 & HASS & 70 \\
\hline 7 & Z & 65 \\
\hline 8 & AS & 0 \\
\hline 9 & WAF & 30 \\
\hline 10 & PH & 60 \\
\hline 11 & MDS & 60 \\
\hline 12 & NHS & 70 \\
\hline 13 & MZS & 60 \\
\hline 14 & AHJ & 60 \\
\hline 15 & AFM & 65 \\
\hline 16 & MEP & 0 \\
\hline 17 & SDYS & 70 \\
\hline 18 & FHB & 55 \\
\hline
\end{tabular}

2.Hasil pekerjaan Subjek

1) Subjek 1 (S1)

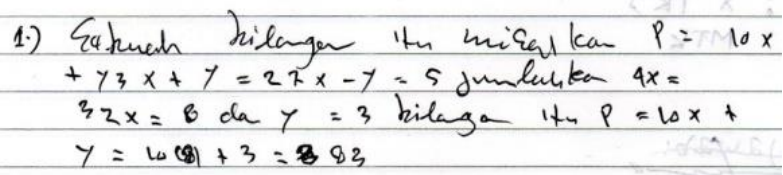

2.) dik $A-B=2$ $a=2+6 \rightarrow$ dimbtitubika

$2 a+6=52$

$2(2+6)+c=52$

$4+2 c+6=25$

$36=25-9$

$36=48$

$b=4 q / 5$

$b=16 \rightarrow$ Enis $k f$ pile I

$a=2+6$

$a=2+6$

$=10$

3.)

2) Subjek

1.) Misaltan Bilangan $A$ dan $B$

(S2)

$10 a+b=$ Bilangan eersebut

$34+B=4$

$a-b=+5+$

$=32 / 4=8$

$a-b=5$

$b=3-5=3$

Jadi $10.8+3=85$

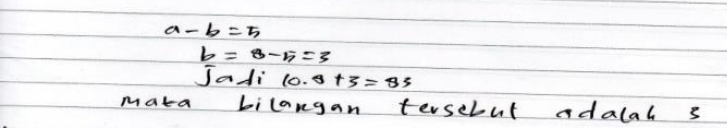

$\int$ Dik $A-B-2$

$a=z+L \rightarrow$ Diselut tulistan

$a+b=52$

$2(2+b)+b=52$

$4+2 b+b=52$

$36=52$

$36=48$
$b=48 / 5$

5)

3) Subjek 3 (S3)

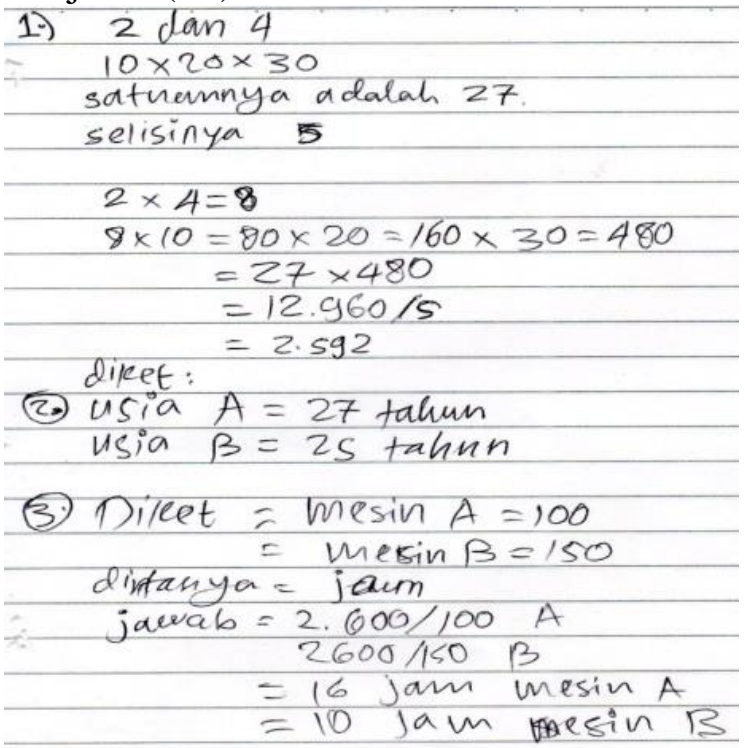

Analisis Data Penelitian 
Berdasarkan paparan data yang telah diuraian di atas terdapat beberapa jenis kesalahan yang dilakukan oleh ketiga subjek dalam menyelesaikan soal cerita matematika pada materi menyelesaikan soal cerita sistem persamaan linear dua variabel berdasarkan prosedur Newman. Kesalahan tersebut meliputi kesalahan membaca soal, kesalahan memahami masalah, kesalahan transformasi, kesalahan keterampilan proses dan kesalahan penulisan jawaban sehingga perlu di lakukan analisis pada tahap selanjutnya untuk melihat lebih jelas kesalahan-kesalahan yang dilakukan ketiga subjek dan untuk mengetahui faktor-faktor penyebab kesalahan subjek pada materi aritmetika. Penjelasan mengenai kesalahan ketiga subjek dan faktor penyebab kesalahan tersebut adalah sebagai berikut:

1. Subjek $1\left(\mathbf{S}_{1}\right)$

\section{Subjek $S_{1}$ soal Nomor 1}

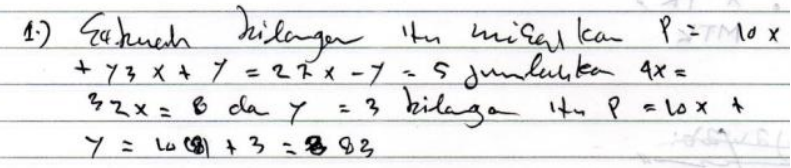

Berdasarkan hasil tes tertulis yang diperoleh, diketahui bahwa subjek $\mathrm{S}_{1}$ melakukan kesalahan. Kesalahan yang dilakukan subjek $S_{1}$ yaitu subjek $S_{1}$ tidak memahami soal, subjek hanya menulis ulang soal yang diberikan, subjek tidak dapat menuliskan apa yang diketahui dan ditanyakan. Dengan demikian dapat disimpulkan bahwa kesalahan yang dilakukan subjek $S_{1}$ pada soal Nomor 1 berdasarkan prosedur Newman adalah kesalahan memahami masalah. Untuk itu, subjek S1 tidak dapat menyelesaikan soal.

\section{Subjek $S_{1}$ Soal Nomor 2}

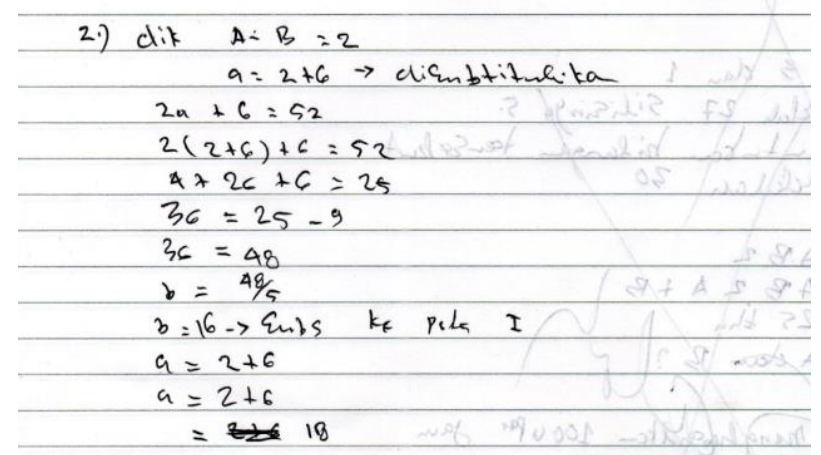

Berdasarkan hasil tes tertulis yang diperoleh, diketahui bahwa subjek $\mathrm{S}_{1}$ melakukan kesalahan. Kesalahan yang dilakukan subjek $S_{1}$ yaitu subjek $S_{1}$ tidak memahami soal, subjek salah dalam menuliskan apa yang diketahui dan ditanyakan. Dengan demikian dapat disimpulkan bahwa kesalahan yang dilakukan subjek $S_{1}$ pada soal Nomor 2 berdasarkan prosedur Newman adalah kesalahan memahami masalah

Berdasarkan hasil tes tertulis yang diperoleh, diketahui bahwa subjek $\mathrm{S}_{1}$ melakukan kesalahan. Kesalahan yang dilakukan subjek $S_{1}$ yaitu subjek $S_{1}$ tidak dapat membuat model matematis dari informasi. Dengan demikian dapat disimpulkan bahwa kesalahan yang dilakukan subjek $\mathrm{S}_{1}$ pada soal Nomor 2 berdasarkan prosedur Newman adalah kesalahan transformasi.

Berdasarkan hasil tes tertulis yang diperoleh, diketahui bahwa subjek $\mathrm{S}_{1}$ melakukan kesalahan. Kesalahan yang dilakukan subjek $S_{1}$ yaitu subjek $S_{1}$ Kesalahan pada perhitungan/ komputasi. Dengan demikian dapat disimpulkan bahwa kesalahan yang dilakukan subjek $S_{1}$ pada soal Nomor 2 berdasarkan prosedur Newman adalah kesalahan keterampilan proses.

\section{Subjek $S_{1}$ Soal Nomor 3}

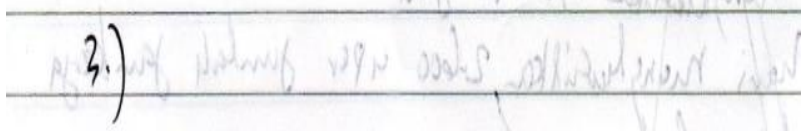

Berdasarkan hasil tes tertulis yang diperoleh, diketahui bahwa subjek $S_{1}$ tidak 
mengerjakan soal Nomor 3, sehingga tidak dapat dianalisis.

\section{Subjek $2\left(\mathbf{S}_{2}\right)$}

\section{Subjek $S_{2}$ Soal Nomor 1}

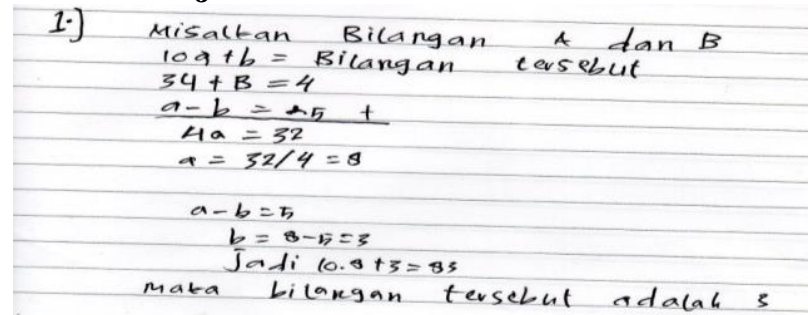

Berdasarkan hasil tes tertulis yang diperoleh, diketahui bahwa subjek $\mathrm{S}_{2}$ melakukan kesalahan. Kesalahan yang dilakukan subjek $S_{2}$ yaitu subjek $S_{2}$ tidak memahami soal, subjek salah dalam menuliskan apa yang diketahui dan ditanyakan. Dengan demikian dapat disimpulkan bahwa kesalahan yang dilakukan subjek $S_{2}$ pada soal Nomor 1 berdasarkan prosedur Newman adalah kesalahan memahami masalah

Berdasarkan hasil tes tertulis yang diperoleh, diketahui bahwa subjek $\mathrm{S}_{2}$ melakukan kesalahan. Kesalahan yang dilakukan subjek $S_{2}$ yaitu subjek $S_{2}$ tidak dapat membuat model matematis dari informasi. Dengan demikian dapat disimpulkan bahwa kesalahan yang dilakukan subjek $S_{2}$ pada soal Nomor 1 berdasarkan prosedur Newman adalah kesalahan transformasi.

\section{Subjek $\mathbf{S}_{2}$ Soal Nomor 2}

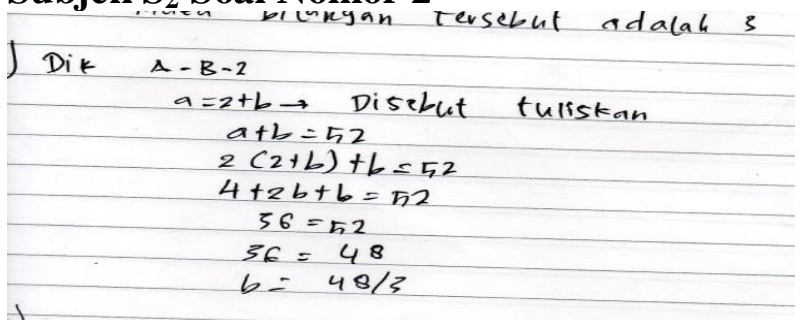

Berdasarkan hasil tes tertulis yang diperoleh, diketahui bahwa subjek $\mathrm{S}_{2}$ melakukan kesalahan. Kesalahan yang dilakukan subjek $S_{2}$ yaitu subjek $S_{2}$ tidak memahami soal, subjek salah dalam menuliskan apa yang diketahui dan ditanyakan. Dengan demikian dapat disimpulkan bahwa kesalahan yang dilakukan subjek $S_{2}$ pada soal Nomor 2 berdasarkan prosedur Newman adalah kesalahan memahami masalah

Berdasarkan hasil tes tertulis yang diperoleh, diketahui bahwa subjek $\mathrm{S}_{2}$ melakukan kesalahan. Kesalahan yang dilakukan subjek $S_{2}$ yaitu subjek $S_{2}$ salah dalam membuat model matematis dari informasi. Dengan demikian dapat disimpulkan bahwa kesalahan yang dilakukan subjek $S_{2}$ pada soal Nomor 2 berdasarkan prosedur Newman adalah kesalahan transformasi.

Subjek $\mathbf{S}_{2}$ Soal Nomor 3

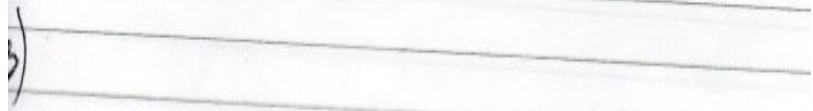

Berdasarkan hasil tes tertulis yang diperoleh, diketahui bahwa subjek $S_{1}$ tidak mengerjakan soal nomor 3 , sehingga tidak dapat dianalisis.

Subjek $3\left(\mathbf{S}_{3}\right)$

Subjek $S_{3}$ Soal Nomor 1

1.) 2 dan 4
$10 \times 20 \times 30$
satuennya adalah 27.
selisinya 5
$\begin{aligned} 2 \times 4 & =8 \\ 8 \times 10 & =80 \times 20=160 \times 30=480 \\ & =27 \times 480 \\ & =12.960 / 5 \\ & =2.592\end{aligned}$

Berdasarkan hasil tes tertulis yang diperoleh, diketahui bahwa subjek $\mathrm{S}_{3}$ melakukan kesalahan. Kesalahan yang dilakukan subjek $S_{3}$ yaitu subjek $S_{3}$ tidak memahami soal, subjek salah dalam menuliskan apa yang diketahui dan ditanyakan. Dengan demikian dapat disimpulkan bahwa kesalahan yang dilakukan subjek $S_{3}$ pada soal Nomor 1 berdasarkan prosedur Newman adalah kesalahan memahami masalah

Berdasarkan hasil tes tertulis yang diperoleh, diketahui bahwa subjek $\mathrm{S}_{3}$ melakukan kesalahan. Kesalahan yang dilakukan subjek $S_{3}$ yaitu subjek $S_{2}$ salah dalam 
membuat model matematis dari informasi. Dengan demikian dapat disimpulkan bahwa kesalahan yang dilakukan subjek $\mathrm{S}_{3}$ pada soal Nomor 1 berdasarkan prosedur Newman adalah kesalahan transformasi.

\section{Subjek $S_{3}$ Soal Nomor 2}

diket:
(2) Usia $A=27$ tahun
usia $B=25$ tahnn

Berdasarkan hasil tes tertulis yang diperoleh, diketahui bahwa subjek $\mathrm{S}_{3}$ melakukan kesalahan. Kesalahan yang dilakukan subjek $\mathrm{S}_{3}$ yaitu subjek $\mathrm{S}_{3}$ tidak memahami soal, subjek salah dalam menuliskan apa yang diketahui dan ditanyakan. Dengan demikian dapat disimpulkan bahwa kesalahan yang dilakukan subjek $S_{3}$ pada soal Nomor 2 berdasarkan prosedur Newman adalah kesalahan memahami masalah

Subjek $\mathrm{S}_{\mathbf{3}}$ Soal Nomor 1

(3.) $\begin{aligned} \text { Dillet }= & \text { mesin } A=100 \\ = & \text { mesin } B=150 \\ \text { dintanya } & =j \text { am } \\ \text { jawab }= & 2.600 / 100 \mathrm{~A} \\ & 2600 / 150 \mathrm{~B} \\ = & 16 \mathrm{jam} \text { mesin } A \\ = & 10 \mathrm{jam} \text { a mesin B }\end{aligned}$

Berdasarkan hasil tes tertulis yang diperoleh, diketahui bahwa subjek $\mathrm{S}_{3}$ melakukan kesalahan. Kesalahan yang dilakukan subjek $S_{3}$ yaitu subjek $S_{3}$ tidak memahami soal, subjek salah dalam menuliskan apa yang diketahui dan ditanyakan. Dengan demikian dapat disimpulkan bahwa kesalahan yang dilakukan subjek $S_{3}$ pada soal Nomor 3 berdasarkan prosedur Newman adalah kesalahan memahami masalah

Berdasarkan hasil tes tertulis yang diperoleh, diketahui bahwa subjek $\mathrm{S}_{3}$ melakukan kesalahan. Kesalahan yang dilakukan subjek $S_{3}$ yaitu subjek $S_{2}$ salah dalam membuat model matematis dari informasi. Dengan demikian dapat disimpulkan bahwa kesalahan yang dilakukan subjek $S_{3}$ pada soal
Nomor 3 berdasarkan prosedur Newman adalah kesalahan transformasi.

\section{Pembahasan Hasil Penelitian}

Berdasarkan paparan data dan analisis yang telah diuraikan di atas, terdapat beberapa kesalahan berdasarkan prosedur Newman yang dilakukan oleh ketiga subjek dalam menyelesaikan soal cerita pada materi aritmetika sosial. Kesalahan tersebut meliputi kesalahan memahami masalah, kesalahan transformasi, kesalahan keterampilan proses, dan kesalahan penulisan jawaban. Secara rinci kesalahan-kesalahan yang dilakukan ketiga subjek dalam menyelesaikan soal cerita berdasarkan prosedur Newman pada materi aritmetika sosial adalah sebagai berikut:

1. Kesalahan memahami masalah

a. Subjek $1\left(\mathrm{~S}_{1}\right)$

$\mathrm{S}_{1}$ melakukan kesalahan memahami masalah yaitu: tidak dapat menuliskan apa yang diketahui dan ditanyakan pada soal nomor 1 daan salah dalam menentukan apa yang diketahui dan ditanyakan pada soal nomor 2 .

b. Subjek $2\left(\mathrm{~S}_{2}\right)$

Subjek 2 melakukan kesalahan memahami masalah yaitu: salah dalam menentukan apa yang diketahui dan ditanyakan pada soal nomor 1 dan 2

c. Subjek $3\left(\mathrm{~S}_{3}\right)$

$\mathrm{S}_{3}$ melakukan kesalahan memahami masalah yaitu: salah dalam menentukan apa yang diketahui dan ditanyakan pada soal nomor 1, 2 dan 3.

Hasil tersebut diatas sesuai dengan pendapat Jha (2012) \& Singh (2010), kesalahan memahami masalah (comprehension errors) adalah suatu kesalahan yang disebabkan karena peserta didik tidak bisa: (1) memahami masalah maksud soal, (2) tidak menuliskan apa yang diketahui dengan lengkap, (2) menuliskan apa yang ditanya dengan tepat. Faktor-faktor yang menjadi penyebab subjek melakukan kesalahan memahami masalah adalah sebagai berikut:

1) Kurang memahami materi

2) terburu-buru dan tidak teliti saat menyelesaikan soal 
3) tidak memeriksa kembali hasil pekerjaan yang telah dikerjakan

pernyataan tersebut di atas didukung pendapat Malau yaitu penyebab kesalahan yang sering dilakukan peserta didik dalam menyelesaikan soal-soal matematika dapat dilihat dari berbagai hal antara lain: (1) kurangnya penguasaan bahasa soal, dan (2) kurang teliti.

2. Kesalahan Transformasi

a. Subjek $1\left(\mathrm{~S}_{1}\right)$

$\mathrm{S}_{1}$ melakukan kesalahan transformasi yaitu: tidak dapat membuat model matematis dari informasi soal nomor 2 .

b. Subjek $2\left(\mathrm{~S}_{2}\right)$

$\mathrm{S}_{2}$ melakukan kesalahan transformasi yaitu: $\mathrm{S}_{2}$ melakukan kesalahan transformasi yaitu: tidak dapat membuat model matematis dari informasi soal nomor 1 dan 2

c. Subjek $3\left(\mathrm{~S}_{3}\right)$

$\mathrm{S}_{3}$ melakukan kesalahan transformasi yaitu: $\mathrm{S}_{3}$ melakukan kesalahan transformasi yaitu: tidak dapat membuat model matematis dari informasi soal nomor 1,2 dan 3

Hasil penelitian di atas didukung pendapat Jha (2012) \& Singh (2010), kesalahan transformasi adalah suatu kesalahan yang disebabkan karena peserta didik tidak bisa: (1) menuliskan rumus apa saja yang akan digunakan untuk menyelesaikan soal, (2) membuat model matematis dari informasi yang disajikan, (3) menentukan operasi hitung yang tepat untuk menyelesaikan soal. Faktor-faktor yang menjadi penyebab peserta didik melakukan kesalahan transformasi adalah sebagai berikut:

1) kurangnya penguasaan bahasa pada soal

2) tidak teliti

3) tidak dapat merencanakan strategi/ rumus karena tidak menguasai materi, baik materi prasyarat maupun materi yang dipelajari.

4) tidak memeriksa kembali hasil pekerjaan yang telah dikerjakan pernyataan di atas sesuai dengan pendapat Malau yaitu penyebab kesalahan yang sering dilakukan peserta didik dalam menyelesaikan soal-soal matematika dapat dilihat dari berbagai hal antara lain: (1) kurangnya penguasaan bahasa matematika dan (2) kurang teliti. Hamalik berpendapat juga faktor-faktor yang menyebabkan peserta didik melakukan kesalahan ditinjau dari faktor internal diantaranya: (1) kurangnya penguasaan bahasa, (2) kurangnya penguasaan materi, baik materi yang sedang dipelajari, ataupun materi prasyarat.

\section{SIMPULAN}

Berdasarkan hasil dan pembahasan pada bab IV maka beberapa simpulan sebagai berikut:

1. Jenis kesalahan yang dilakukan subjek dalam menyelesaikan soal cerita persamaan linear dua variabel berdasarkan prosedur Newman adalah sebagai berikut:

a. Kesalahan memahami masalah

Kesalahan memahami masalah yang dilakukan yaitu subjek tidak dapat menentukan apa yang diketahui dan ditanyakan.

b. Kesalahan transformasi

Kesalahan transformasi yang dilakukan yaitu subjek tidak dapat membuat model matematis dari informasi.

2. Faktor-faktor yang menyebabkan siswa melakukan kesalahan dalam menyelesaikan soal cerita pada materi persamaan linear dua variabel adalah sebagai berikut:

a. Kurangnya penguasaan bahasa pada soal

b. Tidak teliti

c. Tidak dapat merencanakan strategi/rumus karena tidak menguasai materi, baik materi prasyarat maupun materi yang dipelajari

d. Tidak memeriksa kembali hasil pekerjaan yang telaha dikerjakan.

\section{DAFTAR PUSTAKA}

Arikunto, S. 2013. Prosedur Penelitian: Suatu Pendekatan Praktik. Jakarta: Rineka Cipta. 
Newman, M. A. 1977. An analysis of sixthgrade pupils' errors on written mathematicaltasks. In White, A. L. 2009. Diagnostic and Pedagogical Issues with Mathematical Word Problems. Brunei International Journal of Science and Mathematics Education, 1(1): 100-112. Diakses pada tanggal 29 Desember2017. (http://www.sciencedirect.com).

PEMBELAJARAN\%20SOAL\%20CERITA\%2 0OPERASI\%20HITUNG\%20.pdf)

Singh, P., Rahman, A.A., \& Sian. H, T. 2010. The Newman Procedure for Analyzing Primary Four Pupils Errors on Written Mathematical Task: A Malaysian Perspective. Procedia on International Conference onMathematics Education Research 2010 (ICMER 2010), 8(2010): 264-271. Diakses tanggal 5 Januari 2018. (http://www.sciencedirect.com).

Sugiyono. 2015. Metode penelitian pendidikan. Bandung: Alfabeta.

Sukardi, H.M. 2015. Evaluasi Pendidikan Prinsip dan Operasionalnya. Jakarta: Bumi Aksara. 